\title{
Sistema radicular do capim-tanzânia adubado com potássio e magnésio
}

\section{Francisco Antonio Monteiro1, Dylnei Consolmagno Neto²}

\author{
${ }^{1}$ Departamento de Ciência do Solo, ESALQ, Universidade de São Paulo, C.P. 9, CEP: 13418-900, Piracicaba, São Paulo, Brasil. Bolsista \\ do CNPq. \\ 2 Pós-Graduando em Solos e Nutrição de Plantas, ESALQ, Universidade de São Paulo, C.P. 9, CEP: 13418-900, Piracicaba, São Paulo, \\ Brasil. Bolsista do CNPq.
}

RESUMO - Um experimento em casa de vegetação foi conduzido no período da primavera de 2004 visando à obtenção de informações relativas aos atributos do sistema radicular de Panicum maximum Jacq. cv. Tanzânia adubado com combinações de potássio e magnésio em solução nutritiva. Utilizou-se o delineamento experimental de blocos ao acaso, com quatro repetições, em esquema fatorial $5^{2}$ incompleto, com 13 combinações de doses de potássio e magnésio, em mmol/L: 0,4K/0,05Mg; $0,4 \mathrm{~K} / 1,35 \mathrm{Mg} ; 0,4 \mathrm{~K} / 2,65 \mathrm{Mg} ; 3,2 \mathrm{~K} / 0,70 \mathrm{Mg} ; 3,2 \mathrm{~K} / 2,00 \mathrm{Mg} ; 6,0 \mathrm{~K} / 0,05 \mathrm{Mg} ; 6,0 \mathrm{~K} / 1,35 \mathrm{Mg} ; 6,0 \mathrm{~K} / 2,65 \mathrm{Mg} ; 8,8 \mathrm{~K} / 0,70 \mathrm{Mg} ; 8,8 \mathrm{~K} / 2,00 \mathrm{Mg}$; $11,6 \mathrm{~K} / 0,05 \mathrm{Mg} ; 11,6 \mathrm{~K} / 1,35 \mathrm{Mg}$ e $11,6 \mathrm{~K} / 2,65 \mathrm{Mg}$. Após o segundo corte das plantas, realizou-se a coleta das raízes, utilizandose água corrente e água desionizada com auxílio de peneiras de 0,25 e 1,00 mm. As combinações de doses de potássio e de magnésio foram determinantes para a produção de matéria seca de raízes, o comprimento radicular, a concentração de magnésio nas raízes e as concentrações conjuntas de potássio, magnésio e cálcio. De forma isolada, as doses de potássio alteraram a superfície radicular, o comprimento e a superfície radicular específicos e a concentração de potássio nas raízes. As doses de magnésio, isoladamente, promoveram aumento na superfície radicular e decréscimo na concentração de cálcio nas raízes. As maiores respostas do sistema radicular do capim-tanzânia foram obtidas com o fornecimento de potássio de 6,0 a $8,8 \mathrm{mmol} / \mathrm{L}$ e de magnésio de 1,4 a $2,0 \mathrm{mmol} / \mathrm{L}$ na solução nutritiva. A participação do potássio foi de 35 a $53 \%$ e a do magnésio em torno de $20 \%$ na concentração total de potássio, magnésio e cálcio nas raízes.

Palavras-chave: comprimento radicular, gramínea forrageira, macronutrientes, solução nutritiva, superfície radicular

\section{Tanzania guineagrass root system as related to potassium and magnesium fertilization}

\begin{abstract}
A greenhouse experiment was carried out during the Spring 2004 aiming to evaluate Panicum maximum cv. Tanzania root system as related to the combined supply of $\mathrm{K}$ and $\mathrm{Mg}$ in nutrient solutions. A randomized block design was used, with four replications, in an incomplete $5^{2}$ factorial experiment with 13 combinations between $\mathrm{K}$ and $\mathrm{Mg}$ fertilization rates, in mmol/L: $0.4 \mathrm{~K} / 0.05 \mathrm{Mg} ; 0.4 \mathrm{~K} / 1.35 \mathrm{Mg} ; 0.4 \mathrm{~K} / 2.65 \mathrm{Mg} ; 3.2 \mathrm{~K} / 0.70 \mathrm{Mg} ; 3.2 \mathrm{~K} / 2.00 \mathrm{Mg} ; 6.0 \mathrm{~K} / 0.05 \mathrm{Mg} ; 6.0 \mathrm{~K} / 1.35 \mathrm{Mg}$; $6.0 \mathrm{~K} / 2.65 \mathrm{Mg} ; 8.8 \mathrm{~K} / 0.70 \mathrm{Mg} ; 8.8 \mathrm{~K} / 2.00 \mathrm{Mg} ; 11.6 \mathrm{~K} / 0.05 \mathrm{Mg} ; 11.6 \mathrm{~K} / 1.35 \mathrm{Mg}$, and $11.6 \mathrm{~K} / 2.65 \mathrm{Mg}$. Roots were collected after the second harvest of the plants, by washing with tap and deionized water and using 0.25 and $1.00 \mathrm{~mm}$ screens. Potassium and magnesium rates combinations highly influenced root dry weight, specific root length and surface, and root $\mathrm{K}$ concentration. Increasing $\mathrm{Mg}$ rates also increased root surface, but decreased calcium concentration in the grass roots. Maximum responses of Tanzania guineagrass roots were found when $\mathrm{K}$ was supplied between 6.0 and $8.8 \mathrm{mmol} / \mathrm{L}$ and $\mathrm{Mg}$ between 1.4 and $2.0 \mathrm{mmol} / \mathrm{L}$. Root $\mathrm{K}$ concentration ranged between 35 and $53 \%$ and root $\mathrm{Mg}$ concentration about $20 \%$ to the total concentration of potassium, magnesium and calcium in the grass roots.
\end{abstract}

Key Words: forage grass, macronutrients, nutrient solution, root length, root surface

\section{Introdução}

As pastagens ocupam aproximadamente um quarto do território brasileiro e consistem na fonte de alimentos de mais baixo custo para ruminantes. Na busca por espécies forrageiras de alta produtividade, o capim-tanzânia (Panicum maximum cv. Tanzânia) surgiu como opção para utilização em pastagens, especialmente para condições adubadas e de bom manejo.

Em muitos estudos com plantas forrageiras, a ênfase tem sido maior para a parte aérea, resultando em carência acentuada de informações sobre o sistema radicular dessas plantas (Cecato et al., 2004). Entretanto, o sistema radicular está em constante interação com a parte aérea, o que o torna 
um dos responsáveis pelo desenvolvimento da planta, além de se constituir na fonte de carboidratos e proteínas para o início da rebrotação dos capins. O sistema radicular vigoroso reduz o tempo de rebrotação das plantas, diminuindo os ciclos de pastejo e elevando a produção anual da planta forrageira, além de aumentar a resistência das gramíneas ao estresse hídrico e sua competitividade por nutrientes.

O potássio é um cátion de grande relevância nas funções fisiológicas e metabólicas das plantas, enquanto o magnésio é componente da molécula de clorofila, participa na ativação enzimática e é necessário para a estrutura e configuração dos ácidos nucléicos (Mengel \& Kirkby, 2001). A real demanda de magnésio pelas gramíneas forrageiras não tem sido avaliada.

De modo geral, o aumento na quantidade absorvida de um cátion pela planta pode resultar em redução na absorção de um ou mais cátions. Tanto o potássio pode reduzir a absorção de magnésio como o magnésio pode diminuir a absorção do potássio, em razão do antagonismo entre esses minerais (Marschner, 1995). Segundo Mengel \& Kirkby (2001), resultados de pesquisas permitem afirmar que a soma total de cátions em uma planta varia conforme o aumento no suprimento de um cátion, pois geralmente o aumento em um deles faz variar a proporção dos outros cátions presentes. Sabendo da necessidade de potássio e de magnésio para o desenvolvimento do sistema radicular e das relações antagônicas na absorção destes macronutrientes, evidencia-se a necessidade de estudos mais aprofundados sobre o assunto.

Segundo Voorhees et al. (1980), a quantificação da matéria seca de raízes é relativamente simples, porém, não expressa a extensão e o volume de solo ocupado, tornando-se necessário avaliar também o comprimento e a superfície radicular da planta. Conhecendo o comprimento e a superfície radicular, torna-se mais fácil avaliar a área total explorada pelo sistema radicular, um dos fatores determinantes do vigor desse sistema. Além disso, segundo Fitter (1996), quando um nutriente é fornecido em baixa quantidade, as raízes reduzem o diâmetro e aumentam em comprimento, resultando em aumento no comprimento radicular específico.

Neste trabalho objetivou-se avaliar a produção de matéria seca, o comprimento e a superfície, o comprimento e a superfície específicos e as concentrações de potássio, magnésio e cálcio nas raízes do capim-tanzânia adubado com combinações de potássio e magnésio.

\section{Material e Métodos}

Um experimento com a gramínea forrageira Panicum maximum Jacq. cv. Tanzânia foi conduzido em casa de vegetação localizada em Piracicaba, São Paulo. Para obtenção das mudas do capim, sementes foram colocadas para germinar em bandejas plásticas contendo areia lavada com água desionizada. Transplantaram-se 15 mudas para cada vaso e realizaram-se desbastes até restarem cinco plantas homogêneas por vaso.

Utilizaram-se vasos plásticos de 3,6 litros, contendo sílica como substrato (grânulos de aproximadamente $3 \mathrm{~mm}$ liberados de impurezas por múltiplas lavagens com água corrente e desionizada). Nos três primeiros dias após o transplantio das mudas, colocou-se em cada vaso solução diluída a $25 \%$ para cada combinação $\mathrm{K} / \mathrm{Mg}$, que foi substituída pela solução definitiva e trocada a cada 14 dias. As soluções foram circuladas três vezes ao dia e, no início da noite, foram drenadas para um recipiente, onde foram mantidas até a manhã seguinte. O volume de $1 \mathrm{~L}$ foi completado com água desionizada em cada manhã.

Adotou-se o esquema fatorial $5^{2}$ fracionado de Littell $\&$ Mott (1975), com cinco doses de potássio $(0,4 ; 3,2 ; 6,0$; $8,8$ e $11,6 \mathrm{mmol} / \mathrm{L})$ e cinco de magnésio $(0,05 ; 0,70 ; 1,35 ; 2,00$ e $2,65 \mathrm{mmol} / \mathrm{L}$ ) na solução nutritiva, perfazendo um total de 13 combinações: $0,4 \mathrm{~K} / 0,05 \mathrm{Mg} ; 0,4 \mathrm{~K} / 1,35 \mathrm{Mg} ; 0,4 \mathrm{~K} / 2,65 \mathrm{Mg}$; $3,2 \mathrm{~K} / 0,70 \mathrm{Mg} ; 3,2 \mathrm{~K} / 2,00 \mathrm{Mg} ; 6,0 \mathrm{~K} / 0,05 \mathrm{Mg} ; 6,0 \mathrm{~K} / 1,35 \mathrm{Mg}$; $6,0 \mathrm{~K} / 2,65 \mathrm{Mg} ; 8,8 \mathrm{~K} / 0,70 \mathrm{Mg} ; 8,8 \mathrm{~K} / 2,00 \mathrm{Mg} ; 11,6 \mathrm{~K} / 0,05 \mathrm{Mg}$; $11,6 \mathrm{~K} / 1,35 \mathrm{Mg}$ e $11,6 \mathrm{~K} / 2,65 \mathrm{Mg}$. As soluções foram preparadas a partir da solução de Sarruge (1975) modificada conforme as particularidades deste experimento. Para aumentar o suprimento de nitrogênio em relação à solução usual de Sarruge (1975), conforme documentado por Lavres Jr. (2001) e Santos Jr. \& Monteiro (2003), adicionaram-se 3 mmol/L de nitrato de amônio, fracionados em três aplicações similares em dias subseqüentes, de modo que a proporção final entre $\mathrm{N}-\mathrm{NO}_{3}{ }^{-}$e $\mathrm{N}-\mathrm{NH}_{4}{ }^{+}$nas soluções foi de $63,1: 36,9$.

A parte aérea do capim foi submetida a dois cortes: o primeiro aos 36 dias após o transplantio das mudas e o segundo 28 dias após o primeiro corte. As raízes foram separadas do substrato com água corrente e peneiras de 0,25 e 1,00 mm para evitar perdas de material. Após a separação, as raízes foram lavadas com água desionizada. Coletou-se uma amostra de aproximadamente $20 \%$ do total de massa das raízes recém-coletadas para as avaliações, de acordo com o método apresentado por Rossiello et al. (1995). O restante das raízes foi seco em estufa a $65^{\circ} \mathrm{C}$, por 72 horas e, em seguida, foi pesado, triturado em moinho tipo Wiley e analisado em laboratório para as determinações químicas.

A fração separada de raízes foi guardada em recipientes plásticos com água desionizada e colorida com solução de violeta genciana a $50 \mathrm{~g} / \mathrm{L}$. Em seguida, essas raízes foram distribuídas sobre transparências, de modo a evitar 
sobreposição, para digitalização. As imagens digitalizadas foram submetidas ao aplicativo SIARCS (Sistema Integrado para Análise de Raízes e Cobertura do Solo), versão 3.0, para determinação do comprimento e da superfície radicular, utilizando-se metodologia recomendada por Crestana et al. (1994). Posteriormente, determinou-se a massa das subamostras secas e, por meio de regra-de-três com a massa total das raízes, obtiveram-se o comprimento e a superfície total de raízes de cada vaso. Determinaram-se o comprimento radicular específico e a superfície radicular específica dividindo-se, respectivamente, o comprimento e a superfície radicular pela produção de matéria seca de raízes.

Os cátions potássio, magnésio e cálcio tiveram suas concentrações determinadas nas raízes a partir da digestão nítrico-perclórica, conforme metodologia descrita por Sarruge \& Haag (1974). Para determinação de potássio, utilizou-se o método de fotometria de chama e, para magnésio e cálcio, empregou-se a espectrofotometria de absorção atômica.

As concentrações de potássio, magnésio e cálcio, em conjunto, nas raízes do capim-tanzânia foram calculadas transformando-se a concentração de cada nutriente em $\mathrm{g} / \mathrm{kg}$ para $\mathrm{mmol}_{\mathrm{c}} / \mathrm{kg}$. Efetuou-se a soma das três concentrações e obteve-se a porcentagem de cada nutriente nessa concentração total.

As análises estatísticas foram realizadas com auxílio do programa Statistical Analysis System(SAS, 1999). Inicialmente, utilizou-se o teste $\mathrm{F}$ e, em seguida, no caso de significância da interação doses de potássio $\times$ doses de magnésio, procedeu-se à análise de regressão polinomial (superfície de resposta), por meio do procedimento RSREG. Para as variáveis -resposta nas quais a interação potássio $\times$ magnésio não foi significativa, efetuou-se a análise de regressão para as doses de cada nutriente. Adotou-se o nível de significância de 5\% em todos os casos analisados, inclusive para os coeficientes das equações de regressão.

\section{Resultados e Discussão}

A produção de matéria seca de raízes do capim-tanzânia mostrou significância para a interação doses de potássio $\times$ doses de magnésio. Por meio da equação de regressão polinomial (Figura 1), constatou-se que a combinação da dose de potássio de $8,4 \mathrm{mmol} / \mathrm{L}$ com a de magnésio de 1,9 mmol/L (na relação de 4,2:1 entre essas doses) resultou na máxima produção de matéria seca de raízes. Nas doses baixas, tanto de potássio como de magnésio, além da menor massa radicular, as raízes foram mais frágeis e se quebraram facilmente no momento da separação da sílica.

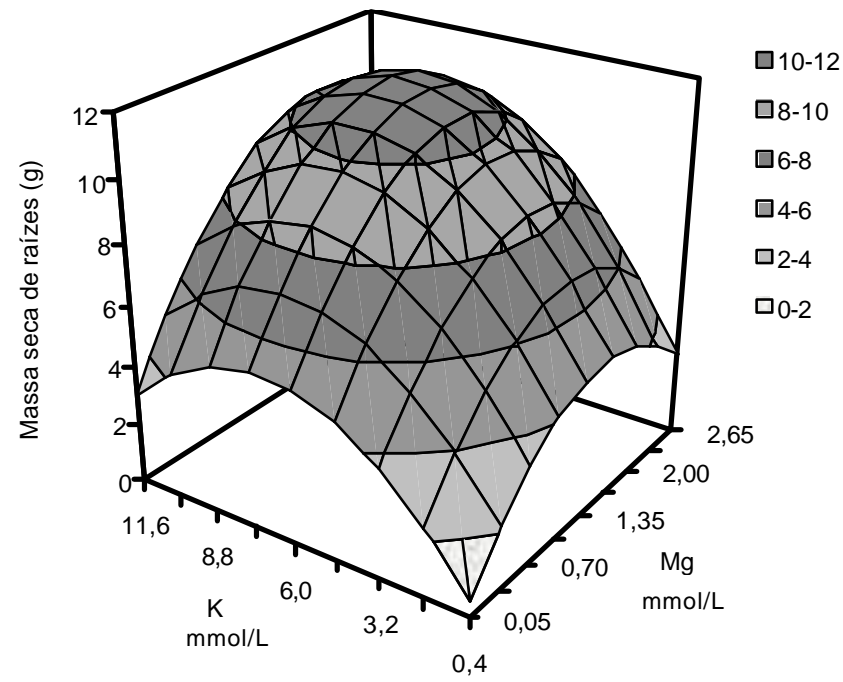

$\hat{\mathrm{Y}}=-0,2512+1,4806 \mathrm{~K}-0,1059 \mathrm{~K}^{2}+5,4199 \mathrm{Mg}-1,7191 \mathrm{Mg}^{2}+$ $0,1489 \mathrm{KMg} ; R^{2}=0,82$

Figura 1 - Produção de matéria seca de raízes do capim-tanzânia em cada combinação de potássio e de magnésio.

Com a utilização de doses elevadas de potássio combinadas a doses moderadas ou baixas de magnésio, não é possível maximizar a produção de matéria seca de raízes, assim como o uso de elevadas doses de magnésio com doses moderadas de potássio também não permite a maximização da produção de raízes. Para que este objetivo fosse alcançado, foram necessárias altas doses de potássio e de magnésio em conjunto. O resultado deste experimento foi próximo ao observado por Mattos \& Monteiro (1998), que, utilizando doses de magnésio $(2 \mathrm{mmol} / \mathrm{L})$ e de potássio, verificaram que a produção de matéria seca de raízes variou com as doses de potássio atingindo a máxima produção com o uso de potássio na dose de 6,9 mmol/L (269 mg/L).

Lavres Jr. (2001), em estudo com capim-mombaça (Panicum maximum Jacq. cv. Mombaça) e aplicando o magnésio na dose de $2 \mathrm{mmol} / \mathrm{L}$, demonstrou que a dose de potássio para maximizar a produção de matéria seca de raízes foi de 10,2 $\mathrm{mmol} / \mathrm{L}$, em condição de aplicação de nitrogênio de 33,4 mmol/L. Pereira (2001), também com capim-mombaça em solução nutritiva quando o magnésio estava constante em $2 \mathrm{mmol} / \mathrm{L}$, verificou que a máxima produção de matéria seca de raízes ocorreu na dose de potássio de 9,2 mmol/L. A máxima produção de raízes observada neste estudo foi em doses muito semelhantes às encontradas por esse autor, comprovando a elevada exi gência desses dois cultivares (tanzânia e mombaça) da espécie Panicum maximum quanto ao suprimento de potássio. Assim, fica evidente a necessidade de equilíbrio 
na adubação com potássio e magnésio quando se objetiva maximizar a produção de matéria seca de raízes.

Corrêa (1996), em experimento para avaliação de combinações entre doses de nitrogênio (3, 15 e $27 \mathrm{mmol} / \mathrm{L})$ e magnésio $(0,2$ e $2 \mathrm{mmol} / \mathrm{L})$ em três cultivares (colonião, tanzânia e vencedor) de Panicum maximum, observou efeito significativo do suprimento de magnésio na produção de matéria seca de raízes apenas quando utilizou a dose mais elevada de nitrogênio ( $27 \mathrm{mmol} / \mathrm{L})$ na solução nutritiva.

Monteiro et al. (1995) constataram que a omissão de magnésio na solução nutritiva para cultivo do capimmarandu (Brachiaria brizantha Stapf. cv. Marandu) reduziu em $70 \%$ a produção de matéria seca de raízes quando comparada ao tratamento completo. Estudando o capimmombaça, Pereira (2001) concluiu que o ponto de máxima produção de matéria seca de raízes ocorreu em dose de magnésio superior a 2,5 $\mathrm{mmol} / \mathrm{L}$.

Poucos são os resultados na literatura sobre a produção de matéria seca de raízes e que tratam exclusivamente da aplicação de magnésio em plantas forrageiras. A maior parte dos estudos relativos ao magnésio envolve a aplicação de calcário, que tem na sua composição cálcio e magnésio, o que dificulta a separação dos efeitos do magnésio no sistema radicular. Trabalhos realizados por Guimarães (2000) e Premazzi \& Mattos (2002) comprovaram que a elevação na saturação por bases do solo por meio da adição de calcário não influenciou a produção de matéria seca de raízes de várias gramíneas forrageiras. Entretanto, Oliveira et al. (2003), testando calagem e adu- bação na recuperação de capim-braquiária (Brachiaria decumbens Stapf.), relataram que, na camada de 0 a $10 \mathrm{~cm}$ de profundidade, possivelmente o magnésio afetou mais o sistema radicular que o cálcio, pois os teores de cálcio nessa camada eram elevados antes da aplicação de calcário e as plantas responderam à calagem, aumentando a produção de matéria seca de raízes.

Ao final do segundo corte do capim-tanzânia, o suprimento de magnésio, de forma similar ao de potássio, influenciou acentuadamente o desenvolvimento do sistema radicular dessa gramínea forrageira. Pela observação das Figuras 2 e 3 é possível afirmar que, para o crescimento vigoroso do sistema radicular, é necessário não somente o fornecimento de elevada dose de potássio, mas também de magnésio.

A interação doses de potássio $\times$ doses de magnésio foi significativa para o comprimento radicular do capimtanzânia e os resultados se ajustaram à equação de regressão polinomial (Figura 4). O máximo comprimento radicular foi obtido na dose de potássio de $10,9 \mathrm{mmol} / \mathrm{L}$ combinada à dose de magnésio de 2,3 $\mathrm{mmol} / \mathrm{L}$, que resultou na relação de 4,7:1. O comprimento radicular foi aproximadamente 10 vezes maior na combinação $10,9 \mathrm{~K}$ e $2,3 \mathrm{Mg}$ que na combinação $0,4 \mathrm{~K}$ e $0,05 \mathrm{Mg}$.

O comprimento radicular é maximizado somente com o uso de alta dose de potássio combinada à alta dose de magnésio. Esse resultado reforça a importância da utilização do magnésio não apenas como corretivo de solo, mas como nutriente em pastagens manejadas de forma intensiva, onde é freqüente a aplicação de adubo potássico.

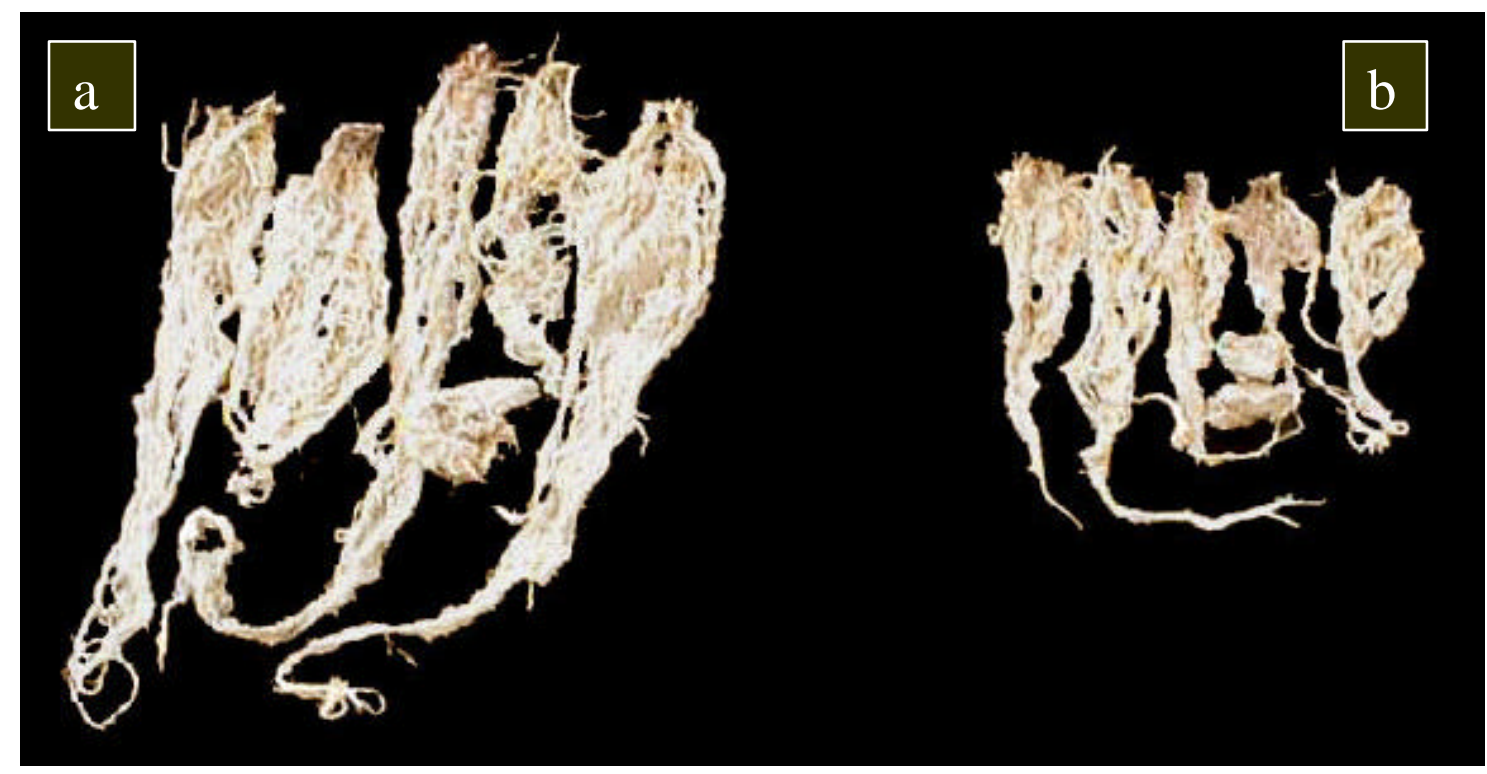

Figura 2 - Raízes do capim-tanzânia desenvolvidas com o suprimento de potássio (0,4 mmol/L) em combinação a magnésio (2,65 mmol/L (a) e $0,05 \mathrm{mmol} / \mathrm{L}$ (b)) na solução nutritiva. 


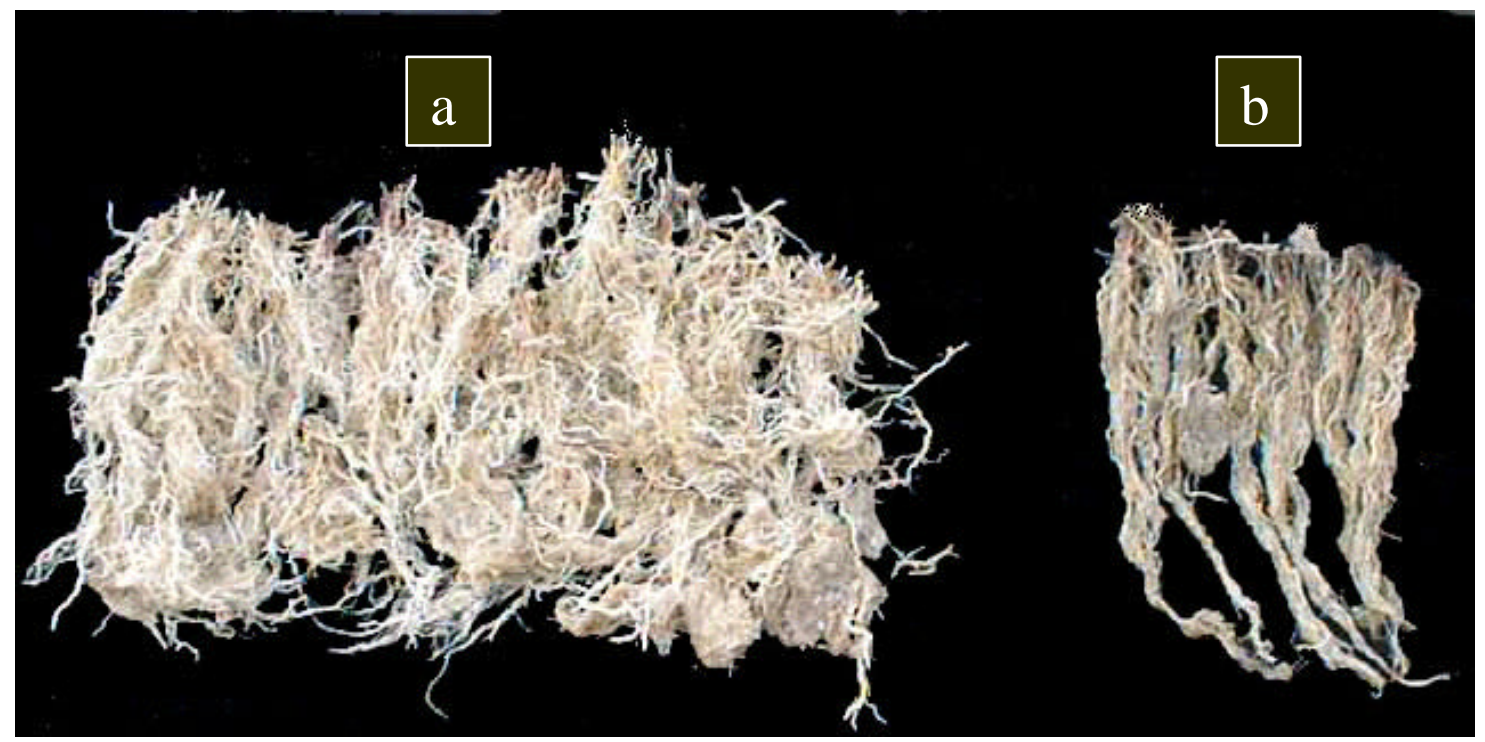

Figura 3 - Raízes do capim-tanzânia desenvolvidas com aplicação de potássio (11,6 mmol/L) em combinação a magnésio (1,35 mmol/L(a) e $0,05 \mathrm{mmol} / \mathrm{L}$ (b)) na solução nutritiva.

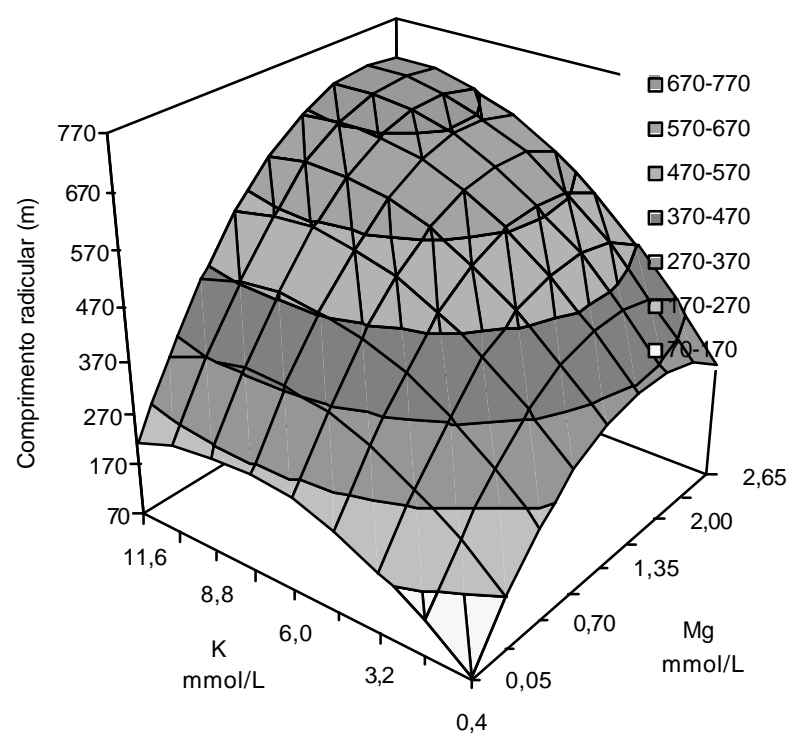

$\hat{\mathrm{Y}}=33,2130+52,4017 \mathrm{~K}-3,3513 \mathrm{~K}^{2}+337,7935 \mathrm{Mg}-94,5540 \mathrm{Mg}^{2}$ $+8,9429 \mathrm{KMg} ; \mathrm{R}^{2}=0,72$

Figura 4 - Comprimento radicular do capim-tanzânia adubado com combinações de potássio e magnésio na solução nutritiva.

A dose de potássio encontrada neste estudo para maximizar o comprimento radicular foi muito próxima da determinada por Lavres Jr. (2001) com uso de solução nutritiva contendo potássio $(11 \mathrm{mmol} / \mathrm{L})$ e magnésio ( $2 \mathrm{mmol} / \mathrm{L})$. Portanto, a dose de potássio estabelecida na solução de Sarruge (1975) não é suficiente para o capim- tanzânia expressar todo o seu potencial de desenvolvimento do sistema radicular.

A análise de variância para superfície radicular mostrou que a interação doses de potássio $\times$ doses de magnésio não foi significativa. Avaliando os efeitos isolados das doses de potássio e magnésio para esta característica das raízes do capim-tanzânia, observou-se significância para essas doses separadamente. O efeito das doses de potássio foi representado por equação de segundo grau (Figura 5a), pela qual verificou-se que a dose de potássio estimada como necessária para máxima superfície radicular foi de $8,6 \mathrm{mmol} / \mathrm{L}$. O efeito do magnésio foi representado por equação exponencial (Figura 5b) e apenas nas doses muito baixas houve redução da superfície radicular do capim.

A dose de potássio para maximização da superfície radicular neste estudo foi inferior à descrita por Lavres Jr. (2001), de 13,4 mmol/L, para máxima superfície radicular do capim-tanzânia.

A interação doses de potássio $\times$ doses de magnésio não foi significativa para o comprimento e a superfície radicular específicos do capim-tanzânia. Estudando os efeitos isolados dos suprimentos de potássio e de magnésio, constatou-se variação significativa somente com as doses de potássio, tanto para o comprimento específico como para a superfície específica. Os resultados ajustaram-se a equações de segundo grau com mínimo comprimento específico na dose de potássio de 7,2 mmol/L (Figura 6a) e mínima superfície específica na dose de potássio de 6,7 mmol/L (Figura 6b).

Elevando a dose de potássio na solução nutritiva até 7,2 $\mathrm{mmol} / \mathrm{L}$, ocorreu redução no comprimento radicular 


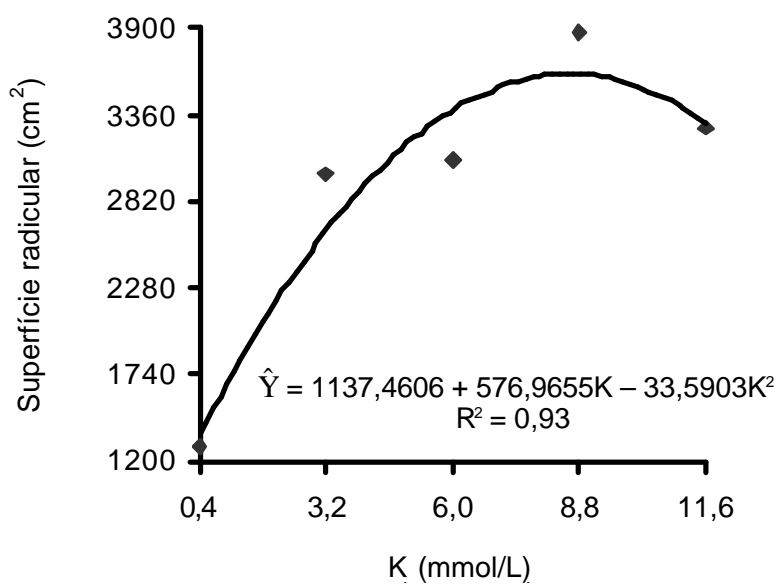

b

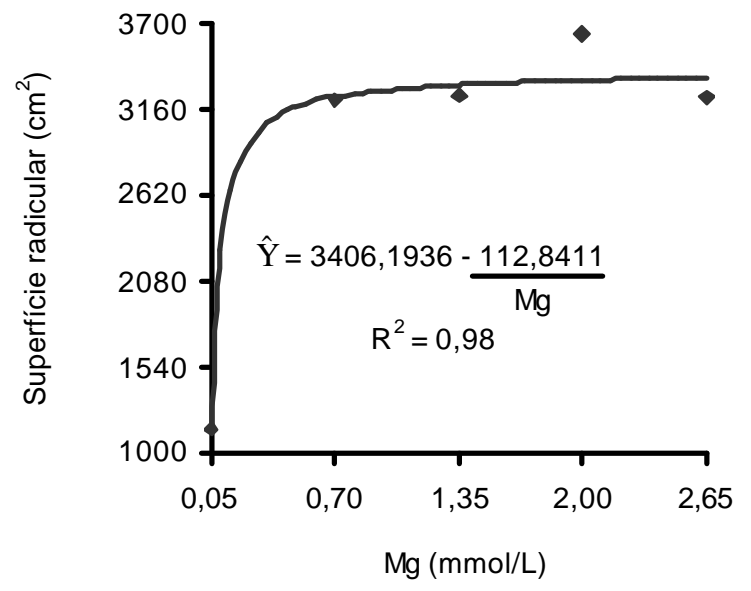

Figura 5 - Superfície radicular do capim-tanzânia em cada vaso, em função das doses de potássio (a) e de magnésio (b) na solução nutritiva.

específico do capim-tanzânia, em virtude da maior espessura das raízes. Para superfície radicular específica, o mesmo comportamento foi observado, porém, com menor superfície radicular específica na dose de potássio de 6,7 mmol/L. Quando o potássio foi suprido em baixa concentração, tanto o comprimento específico como a superfície específica foram maiores, ou seja, o diâmetro médio das raízes diminuiu com o aumento (até certo ponto) no suprimento de potássio, o que, segundo Fitter (1996), é um mecanismo da planta para aumentar a área de exploração das raízes e absorver mais nutrientes, quando submetida a estresse com carência nutricional. Os resultados deste estudo foram similares aos descritos por Lavres Jr. (2001), que observou menor superfície radicular específica e menor comprimento radicular específico do capim-mombaça nas doses de potássio de 7,2 e 7,3 mmol/L, respectivamente.

A análise de variância comprovou que não houve significância da interação doses de potássio $\times$ doses de magnésio na concentração de potássio nas raízes do capimtanzânia. A concentração de potássio nas raízes desse

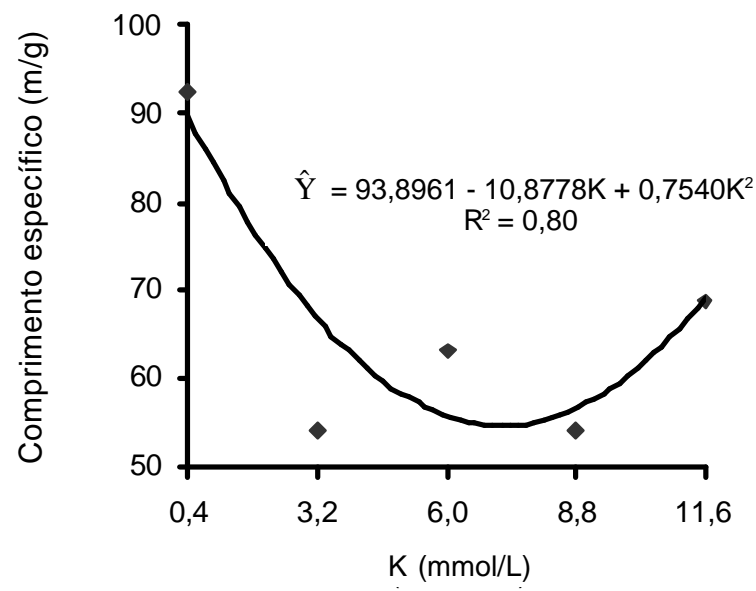

b

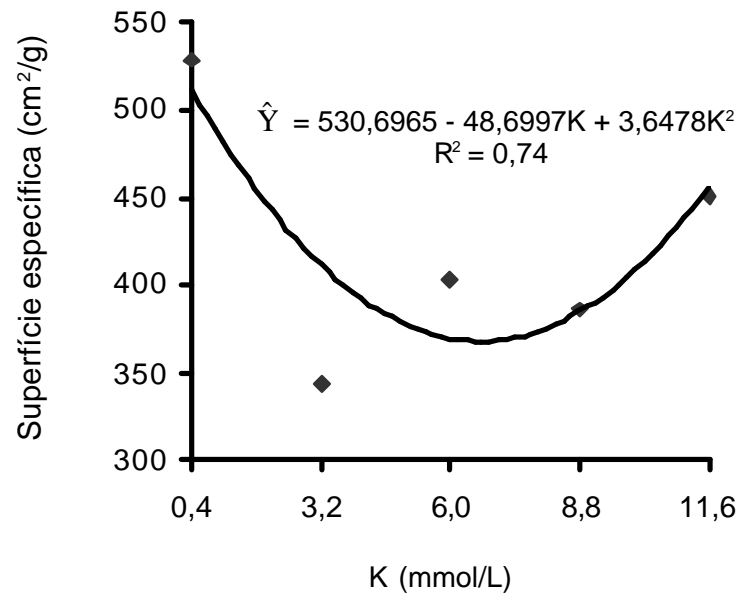

Figura 6 - Comprimento específico (a) e superfície específica (b) das raízes do capim-tanzânia adubada com potássio na solução nutritiva.

capim, avaliada em relação aos efeitos isolados do suprimento dos dois nutrientes, variou linearmente com as doses de potássio (Figura 7), indicando que a dose de potássio de 11,6 mmol/L não foi suficiente para maximizar a concentração de potássio nas raízes.

Pereira (2001), em experimento com doses de potássio em capim-mombaça, também verificou aumento linear na concentração de potássio nas raízes da gramínea com as concentrações de potássio de 1,8 a 13,0 g/ kg entre as doses de potássio de 0,25 e 12,0 $\mathrm{mmol} / \mathrm{L}$, respectivamente. Lavres Jr. (2001), utilizando doses de nitrogênio e potássio em solução nutritiva para o capim-mombaça, também constatou que o aumento no suprimento de potássio promoveu maior concentração de potássio nas raízes, que variou de valores próximos a 0 até $12 \mathrm{~g} / \mathrm{kg}$ entre as doses de potássio de 0,5 e $11,0 \mathrm{mmol} / \mathrm{L}$.

A interação doses de potássio $\times$ doses de magnésio foi significativa para a concentração de magnésio nas raízes, que elevou conforme o aumento das doses de magnésio na solução nutritiva (Figura 8). Entretanto, quanto mais baixa 
a dose de potássio combinada à dose de magnésio, mais elevada a concentração de magnésio nas raízes. Mantendo-se constante a dose de potássio em 11,6 $\mathrm{mmol} / \mathrm{L}$ e variando a dose de magnésio, a máxima concentração de magnésio nas raízes foi de $0,6 \mathrm{~g} / \mathrm{kg}$. Quando se forneceu a mais baixa dose de potássio e alteraram-se as doses de magnésio, essas concentrações variaram de 0,4 a $1,5 \mathrm{~g} / \mathrm{kg}$. Esses resultados realçam o antagonismo entre esses dois nutrientes também no capim-tanzânia.

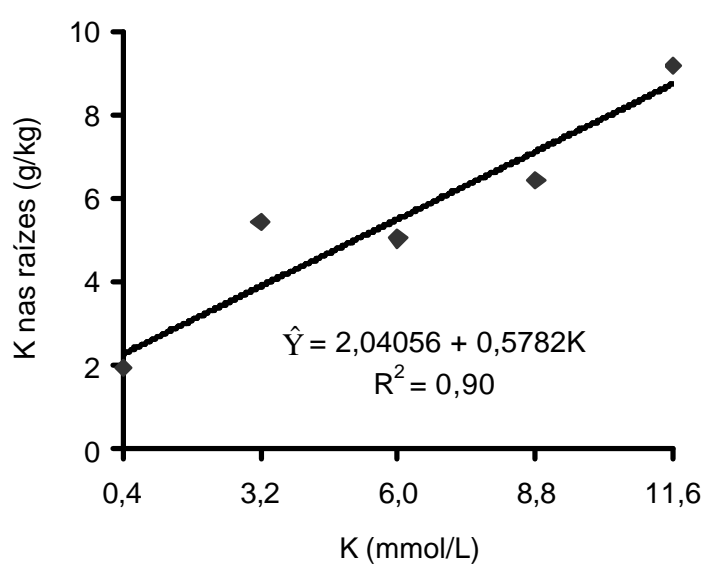

Figura 7 - Concentração de potássio nas raízes do capimtanzânia adubado com potássio na solução nutritiva.

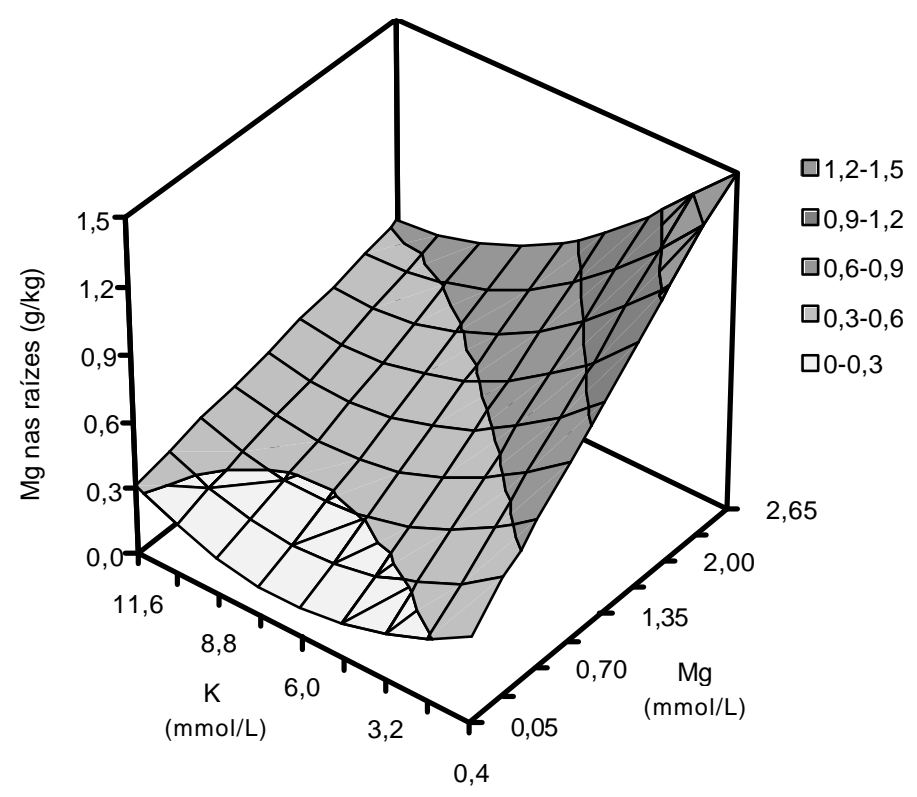

$\hat{\mathrm{Y}}=0,4108-0,0908 \mathrm{~K}+0,0071 \mathrm{~K}^{2}+0,4323 \mathrm{Mg}+0,0063 \mathrm{Mg}^{2}-$ $0,0291 \mathrm{KMg} ; \mathrm{R}^{2}=0,87$

Figura 8 - Concentração de magnésio nas raízes do capimtanzânia adubado com combinações de potássio e magnésio na solução nutritiva.
Em experimento com capim-mombaça em solução nutritiva, Pereira (2001) relatou que as concentrações de magnésio nas raízes aumentaram linearmente de acordo com as doses de magnésio na solução nutritiva e variaram de 0,3 a $1,6 \mathrm{~g} / \mathrm{kg}$.

A interação doses de potássio $\times$ doses de magnésio não foi significativa para a concentração de cálcio nas raízes do capim-tanzânia. A concentração de cálcio nas raízes, avaliada em relação aos efeitos isolados do suprimento desses dois macronutrientes, variou significativamente apenas com as doses de magnésio (Figura 9). Os resultados ajustaram-se à equação de primeiro grau, comprovando que, quanto maior a concentração de magnésio na solução nutritiva, menor a de cálcio nas raízes.

A participação percentual de potássio na matéria seca de raízes do capim-tanzânia aumentou de acordo com as doses de potássio aplicadas (Figura 10). A participação do magnésio, no entanto, foi crescente com as doses de magnésio, dentro de cada dose de potássio, e decrescente em relação às doses de potássio. A porcentagem de cálcio na concentração total das raízes teve maiores reduções quando se elevaram as doses de potássio na solução nutritiva.

Observaram-se efeitos benéficos das doses de potássio na produção de matéria seca, no comprimento e na superfície de raízes, que foram mais expressivos quando as doses de potássio foram iguais ou superiores a $8,8 \mathrm{mmol} / \mathrm{L}$ na solução nutritiva. Em condições de mais altas produtividades, as porcentagens de potássio, no total dos três macronutrientes, na matéria seca das raízes oscilaram entre 51 e $67 \%$ (Figura 10). Uma vez que, para maximizar a produção das raízes do capim-tanzânia, a proporção de potássio

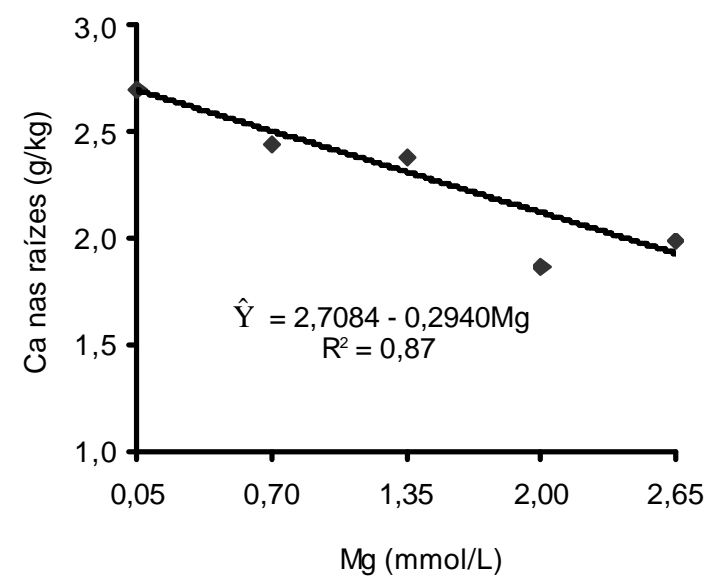

Figura 9 - Concentração de cálcio nas raízes do capim-tanzânia adubado com concentrações de magnésio na solução nutritiva. 


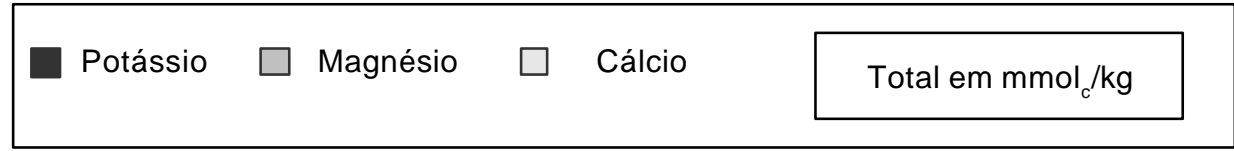

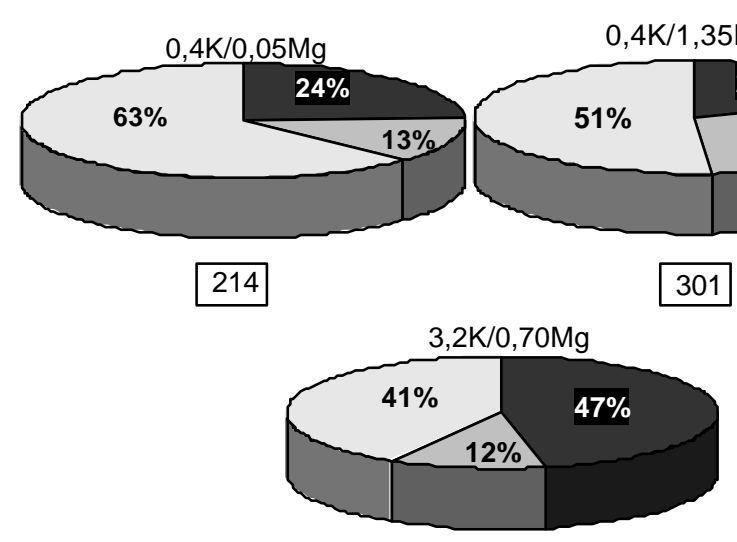

259
301

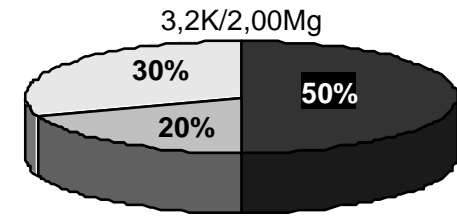

317

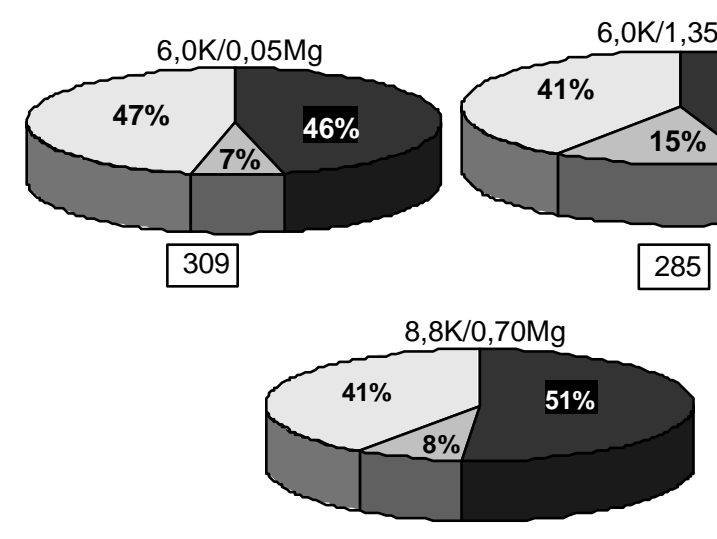

337
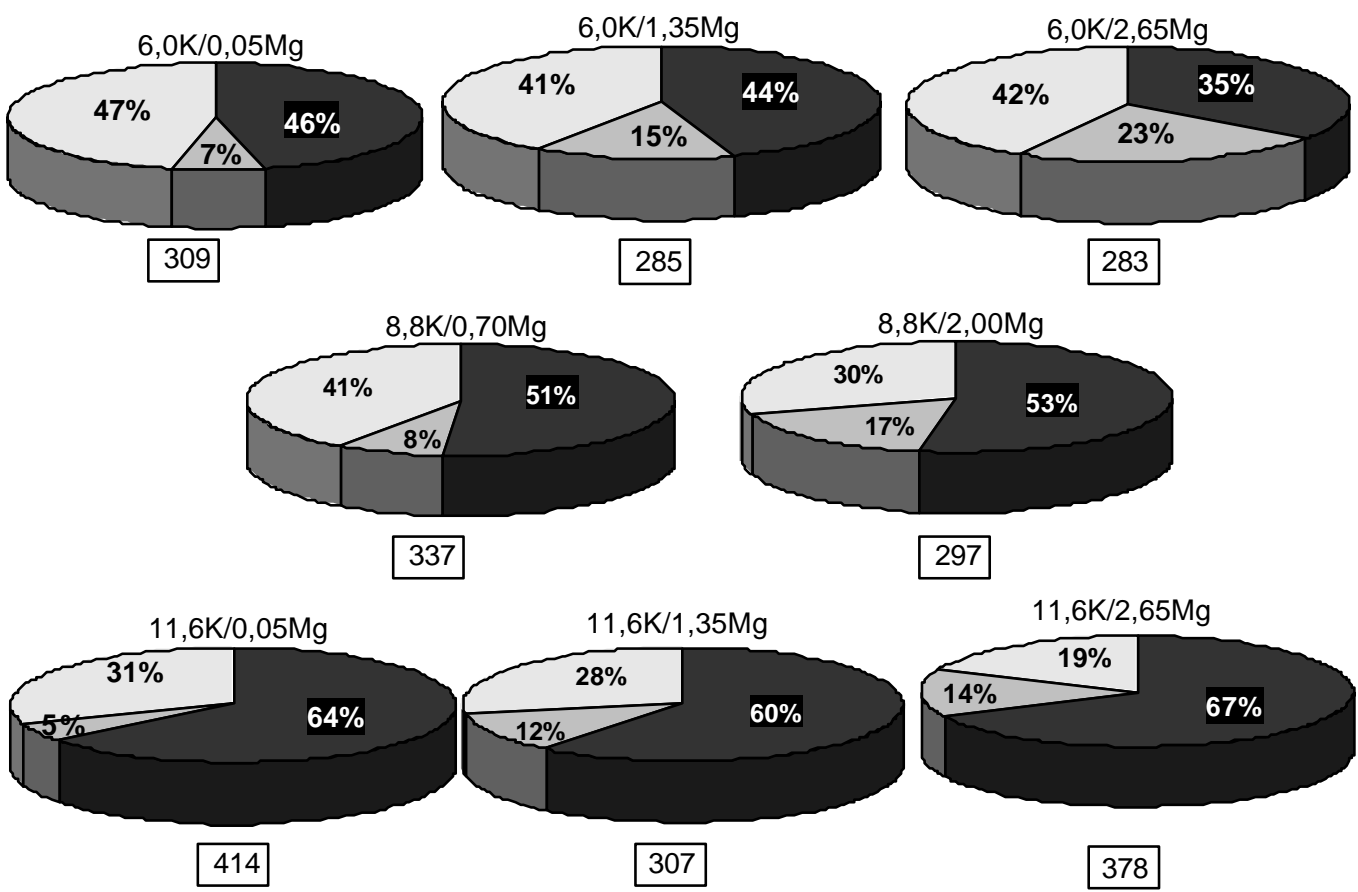

283

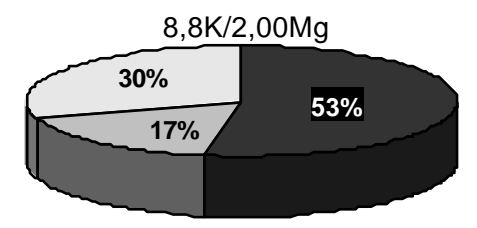

297

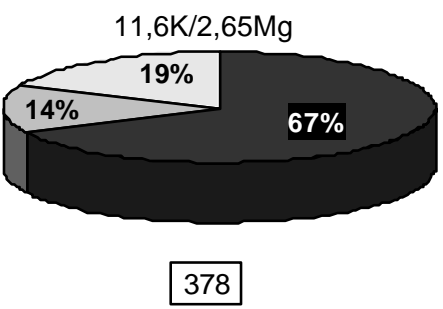

Figura 10 - Contribuições de potássio, magnésio e cálcio na concentração total desses três macronutrientes nas raízes do capimtanzânia adubado com combinações de potássio e magnésio na solução nutritiva.

na matéria seca de raízes mantém-se nessa faixa, novamente destaca-se a elevada exigência de potássio pelo capimtanzânia. As maiores produções de matéria seca de raízes e comprimento radicular foram observadas quando as doses de magnésio estavam próximas a $2 \mathrm{mmol} / \mathrm{L}$ na solução, o que correspondeu à participação de aproximadamente 12 a $23 \%$ do magnésio no total dos três macronutrientes na matéria seca das raízes.

Segundo Mengel \& Kirkby (2001), a soma total de cátions em uma planta ou em parte dela é pouco variável, mesmo quando ocorre variação no fornecimento individual de cátions, pois o aumento da concentração de um cátion no meio usualmente resulta em menor absorção de outro cátion, em razão do antagonismo entre eles. Esses mesmos autores relataram resultados de experimentos com girassol (Helianthus annuusL.), nos quais a elevação de doses de magnésio reduziu as concentrações dos cátions sódio e cálcio e elevou a concentração de magnésio, de modo que a soma total dos cátions se manteve quase constante. Neste experimento, a concentração total dos três cátions 
nas raízes variou de $214 \mathrm{a} 414 \mathrm{mmol}_{\mathrm{c}} / \mathrm{kg}$, de acordo com as doses de potássio e magnésio fornecidas ao capimtanzânia. Coutinho et al. (2004) também afirmaram que tem sido constante a soma dos três cátions, expressos em $\mathrm{mmol}_{\mathrm{c}} / \mathrm{kg}$ de tecido da planta, a qual representa o total de carga positiva absorvida. Os relatos desses autores referem-se à parte aérea das plantas, o que evidencia a necessidade de mais estudos sobre esse assunto, porém envolvendo o sistema radicular.

\section{Conclusões}

As combinações de doses de potássio e de magnésio são determinantes para a concentração de magnésio, para a proporção conjunta de potássio, magnésio e cálcio nas raízes e para o comprimento e a massa radicular do capimtanzânia. De forma isolada, as doses de potássio alteram a superfície radicular, o comprimento e a superfície radicular específicos e a concentração de potássio nas raízes do capim-tanzânia. As doses de magnésio, isoladamente, influenciam a superfície radicular do capim-tanzânia e a concentração de cálcio nas raízes. As máximas respostas do sistema radicular do capim-tanzânia são alcançadas com fornecimento de potássio $(6,0$ a $8,8 \mathrm{mmol} / \mathrm{L})$ e magnésio (1,4 e 2,0 mmol/L) na solução nutritiva e com participação de 44 a $53 \%$ de potássio e de 15 a $23 \%$ de magnésio na concentração total de potássio, magnésio e cálcio nas raízes das plantas.

\section{Literatura Citada}

CECATO, U.; JOBIM, C.C.; REGO, F.C.A. et al. Sistema radicular - componente esquecido das pastagens. In: SIMPÓSIO SOBRE MANEJO ESTRATÉGICO DA PASTAGEM, 2., 2004, Viçosa, MG. Anais... Viçosa, MG: Universidade Federal de Viçosa, 2004. p.159-207.

CORREAA, B.D. Doses de nitrogênio e de magnésio afetando aspectos produtivos e bioquímicos dos capins Colonião, Tanzânia-1 e Vencedor. Piracicaba: Escola Superior de Agricultura "Luiz de Queiroz", 1996. 76p. Dissertação (Mestrado em Solos e Nutrição de Plantas) - Escola Superior de Agricultura "Luiz de Queiroz", 1996.

COUTINHO, E.L.M.; SILVA, A.R.; MONTEIRO, F.A. et al. Adubação potássica em forrageiras. In: SIMPÓSIO SOBRE MANEJO DA PASTAGEM, 21., 2004, Piracicaba. Anais... Piracicaba: Fundação de Estudos Agrários Luiz de Queiroz, 2004. p.219-277.

CRESTANA, S.; GUIMARÃES, M.S.; JORGE, L.A.C. et al. Avaliação da distribuição de raízes no solo auxiliada por processamento de imagens digitais. Revista Brasileira de Ciência do Solo, v.18, n.3, p.365-371, 1994.

FITTER, A. Characteristics and functions of root systems. In: WAISEL, Y.; ESHEL, A.; KAFKAFI, U. (Eds.) Plants roots: the hidden half. New York: Marcel Dekker, 1996. p.1-20.

GUIMARÃES, G.F.P.B. Avaliação de quatro forrageiras tropicais cultivadas em dois solos da ilha de Marajó-PA submetidos a crescentes saturações por bases. Piracicaba: Escola Superior de Agricultura "Luiz de Queiroz", 2000. 197p. Dissertação (Mestrado em Ciência Animal e Pastagens) - Escola Superior de Agricultura "Luiz de Queiroz", 2000.

LAVRES JR., J. Combinações de doses de nitrogênio e potássio para capim-Mombaça. Piracicaba: Superior de Agricultura "Luiz de Queiroz", 2001. 103p. Dissertação (Mestrado em Solos e Nutrição de Plantas) - Escola Superior de Agricultura "Luiz de Queiroz", 2001.

LITTELL, R.C.; MOTT, G.O. Computer assisted design and analysis of response surface experiments in agronomy. Soil and Crop Society of Florida Proceedings, v.34, n.5, p.94-97, 1975.

MARSCHNER, H. Mineral nutrition of higher plants. 2.ed. London: Academic Press, 1995. 889p.

MATTOS, W.T.; MONTEIRO, F.A. Respostas de braquiária brizantha a doses de potássio. Scientia Agrícola, v.55, n.3, p.428-437, 1998.

MENGEL, K.; KIRKBY, E.A. Principles of plant nutrition. 5.ed. Dordrechth: Kluwer Academic Publishers, 2001. 849p.

MONTEIRO, F.A.; RAMOS, A.K.B.; CARVALHO, D.D. et al. Cultivo de Brachiaria brizantha Stapf. cv. Marandu em solução nutritiva com omissão de macronutrientes. Scientia Agrícola, v.52, n.1, p.135-141, 1995.

OLIVEIRA, P.P.A.; BOARETTO, A.E.; TRIVELIN, P.C.O. et al. Liming and fertilization to restore degraded Brachiaria decumbens pastures grown on an entisol. Scientia Agrícola, v.60, n.1, p.125-131, 2003.

PEREIRA, W.L.M. Doses de potássio e de magnésio em solução nutritiva para o capim-Mombaça. Piracicaba: Escola Superior de Agricultura "Luiz de Queiroz", 2001. 128p. Tese (Doutorado em Solos e Nutrição de Plantas) - Escola Superior de Agricultura "Luiz de Queiroz", 2001.

PREMAZZI, L.M.; MATTOS, H.B. Saturação por bases como critério para recomendação de calagem em duas espécies de gramíneas tropicais. Boletim de Indústria Animal, v.59, n.2, p.125-136, 2002 .

ROSSIELO, R.O.P.; ARAÚJO, A.P.; MANZATTO, C.V. et al. Comparação dos métodos fotoelétricos e da interação na determinação de área, comprimento e raio médio radicular. Pesquisa Agropecuária Brasileira, v.30, n.5, p.633-638, 1995

SANTOS JR., J.D.G.; MONTEIRO, F.A. Nutrição em nitrogênio do capim-marandu submetido a doses de nitrogênio e idades de crescimento. Boletim de Indústria Animal, v.60, n.2, p.139146, 2003.

SARRUGE, J.R. Soluções nutritivas. Summa Phytopathologica, v.1, n.3, p.231-233, 1975.

SARRUGE, J.R.; HAAG, H.P. Análises químicas em plantas. Piracicaba: Escola Superior de Agricultura "Luiz de Queiroz", 1974. 54p.

STATISTICAL ANALYSIS SYSTEM - SAS. User's guide statistics : version 8.0 edition. Cary: SAS Institute, 1999. 956p.

VOORHEES, W.B.; CARLSON, V.A.; HALLAUER, E.A. Root lenght measurement with a computer-controlled digital scanning microdensitometer. Agronomy Journal, v.72, n.2, p.847-850, 1980. 